GOSPODARKA SUROWCAMI MINERALNYMI - MINERAL RESOURCES MANAGEMENT

2015

Volume $31 \quad$ Issue $4 \quad$ Pages 161-188

DOI 10.1515/gospo-2015-0037

\title{
The impact assessment of quality parameters of coal and waste rock on the value of mining investment projects - hard coal deposits
}

\section{Introduction}

Functioning in a dynamically variable market environment forces mining companies to rationalize decision-making processes related to the launching of new investments and effective management of resource deposits.

The basis for effective investment decisions is undoubtedly a proper assessment of the potential investment. The quality, accuracy, and reliability of the valuation of new investment projects - geological and mining assets - increases the guarantee of profitability and a positive return on invested capital.

According to the POLVAL code, the geological and mining assets (GMA) should be understood as: "...mineral deposits, anthropomorphic deposits or their parts and the related: intangibles, fixed assets, movable property and securities" (Polval 2008).

Investment projects, both geological and mining, are characterized by a long investment process and high capital intensity, usually a long-term operational phase, limited flexibility of the production process, low predictability of mineral raw material prices and the strong influence of geological and mining conditions associated with the deposit, extraction and processing technology on the efficiency of investment. This often results in above-average risk accompanying investment in the mining industry (Saługa 2011).

* Ph.D. Eng., The Mineral and Energy Economy Research Institute of the Polish Academy of Sciences, Krakow, Poland; e-mail: kopacz@min-pan.krakow.pl 
Economic valuation and economic efficiency of geological and mining assets is a complex issue. The reasons for this complexity involve the variety of definitions, approaches and methods used in the valuation process.

This value can be understood as - for example: fair value, book value or market value; the concept of value is very closely related to the method of valuation (Damodaran 2007).

Valuation methods are dominated by the three approaches, namely the income approach, market approach and cost approach (Panfil and Szablewski 2006). It should be noted that the net present value (NPV), the internal rate of return (IRR), comparative methods and replacement value (Wanielista et al. 2002) are among the most common methods of the valuation of investments in the mining industry (Wanielista et al. 2002). The most advanced methods include the decision tree analysis, the real options analysis (ROA), and the Monte Carlo simulation (Kopacz 2009).

The impact of coal quality on its price and market attractiveness has been studied by, among others, Blashke, Lorenz and Grudziński (Lorenz et al. 2002), Kaula and Pielot (Kaula and Pielot 2005), Naworyta and Mazurek (Naworyta and Mazurek 2010), or Grudziński (Grudziński 2012). Various aspects of assessing the impact of geological and mining conditions, exploitation and modeling of the production process taking into account cost issues have also been studied by Lisowski (Lisowski 2001), Przybyła and Chmiela (Przybyła and Chmiela 2007), Jaszczuk and Kania (Jaszczuk and Kania 2008), Sobczyk (Sobczyk 2009), Magda et al. (Magda et al. 2002), Brzychczy (Brzychczy 2012), Karbownik (Karbownik 1987), Włodarski and Bijańska (Włodarski and Bijańska 2014), Lubosik (Lubosik 2009), Rajwa (Rajwa 2007), Turek, Jonek-Kowalska, Michalak (Turek ed. 2013), or Fuksa (Fuksa 2013).

\section{The justification of the topic of the paper, thesis and aim of the study}

Numerous studies conducted by The Mineral and Energy Economy Research Institute of the Polish Academy of Sciences, as well as the author's personal experience in the valuation of investment projects in the coal and copper mining industry, lead to the conclusion that the deposit is one of the key areas of value creation in mining companies.

The problem in assessing the impact of the quality parameters of the output or waste rock on the value of investment projects in the mining industry is often underestimated in the valuation process. This is due to several reasons:

1. Continued insufficient awareness of the importance, direction and strength of the impact of variable geological and mining parameters of mineral deposits and the quality of raw minerals on the value of geological and mining assets. What is more, quantifying the variables that are difficult to measure and less predictable is also problematic.

2. The structures of revenues, expenses and costs of already active mines, which do not necessarily correspond with the assessed beds, are often used as a point of reference in calculations concerning the deposits adjacent to the primary deposit. The problem 
of selecting the proper twin asset is a known issue in the valuation process (Brealey and Myers 2001).

3. Qualifying balance resources to industrial resources (despite the current definition of industrial resources in the Regulation of the Minister of the Environment (Ministry of the Environment, Ordinance 2005) does not need to ultimately ensure the economic efficiency of the extraction process; it is based on estimates of experts, often without access to digital models of the mineral deposits. Additionally, the amount of industrial resources usually decreases once the longwall development design is made. What is more, the assessment of the quality of exploitable resources is also changing along with the following stages of deposit prospecting and exploration.

4. Currently, almost no coal mining company in Poland has a model allowing them to dynamically adjust, taking into account the impact of an above-average amount of gangue, which expresses the deteriorating value of net coal output (coal yield), the assessment of the economic efficiency of mining activities. The estimation alone, which is forecasting the contamination of the output, is already a problem.

5. The low efficiency of mining cost assessment is further compounded by limited access to appropriate digital geological databases or the lack of proper cost accounting.

6. The valuation (assessment) of geological and mining assets are often made by inexperienced analysts (valuators) or people without the proper permissions.

7. Finally, the possibility of controlling the level of extraction in conditions of deteriorating deposit thickness is limited. In addition, the management of mines demonstrates relatively little interest in awarding bonuses for the quality of extracted coal.

It is suggested that there is a significant cost impact on the economic efficiency of the mining process of waste rock at the bottom of the mine. The above-standard increase in the amount of gangue, assuming coal output at the same level, may anticipate rhythm disturbances in the mining process, shortening of effective working hours, and additional costs associated with emergency repairs and, as a result, an increase in total operating expenses (Kopacz 2015).

The paper attempts to demonstrate the importance of proper evaluation of coal quality parameters and the impact of variable quantities of gangue, represented by net coal output (coal yield), on the value of investment projects and, indirectly, the deposits. However, the valuation is limited to the operational phase in the life cycle of a hypothetical coal mine.

The paper focuses on two major questions:

- The problem of proper impact assessment of key decision variables (components of revenues and expenses) on the value of investment projects.

- Selection of initial values that are the most important (in the valuation process) for the parameters of the economic model. This applies in particular for new deposits valuated by comparison (analogies) to deposits currently active, often adjacent (the so-called twin deposits). The data on the reference fields may include both mining costs, the level of investment outlays and/or the scale of achievable revenues from the sale of specified coal products. 
The objectives of the research were carried out by constructing a dedicated economic model and the measurement of direction and strength of impact of:

- calorific value, the percentage of ash and sulfur

- variable amounts of gangue, represented by coal yield to the total amount of output extracted from mines

on the value and variability of total revenues, respectively, and, finally, on the valuation of a hypothetical coal mine in the operational phase using the NPV and IRR methods.

The research results are included in the results for the baseline scenario and additionally two other "low" and "high" scenarios are presented in a summary form (only the results and conclusions of the evaluation). The introduction of additional scenarios was aimed at illustrating a significant impact on the value of the analyzed variables on the geological and mining projects, taking into account the limitations of the NPV method and the results obtained for other than baseline levels of key decision variables.

It should also be noted that neither in practice nor in the literature are there solutions which allow for dynamic adjustment of the production according to the projected amount of gangue using the profit formula and the revenues using the quality function of coal produced. This does not mean, however, that mining has not mastered other techniques for assessing the impact of coal contamination on the results of mining process.

\section{Research method}

\subsection{The approach to the analysis, assessment model and data sources}

In order to verify the theory about the relationship between the quality parameters of coal and rock waste with the value of geological and mining projects, the paper examined the strength and direction of impact of:

- calorific value and percentage content of sulfur and ash on the sales revenue

- gangue, represented by varying level of net coal output (coal yield), on the overall cost of extraction

The summary of gangue sources in the longwall face, identification of revenue and cost based on components in the valuation model, along with coal quality and gangue quantities for a typical longwall, are presented in Figure 1.

The idea behind the analysis assumes a separate study on the impact of coal quality parameters and gangue on the value of investment in hard coal mining, measured using the NPV and IRR methods, as in the case of a classical sensitivity analysis (Rogowski 2004) $)^{1}$.

1 The classic sensitivity analysis assumes studying the impact of only one decision parameter on a projected variable at one time. Other parameters remain at their baseline values). 

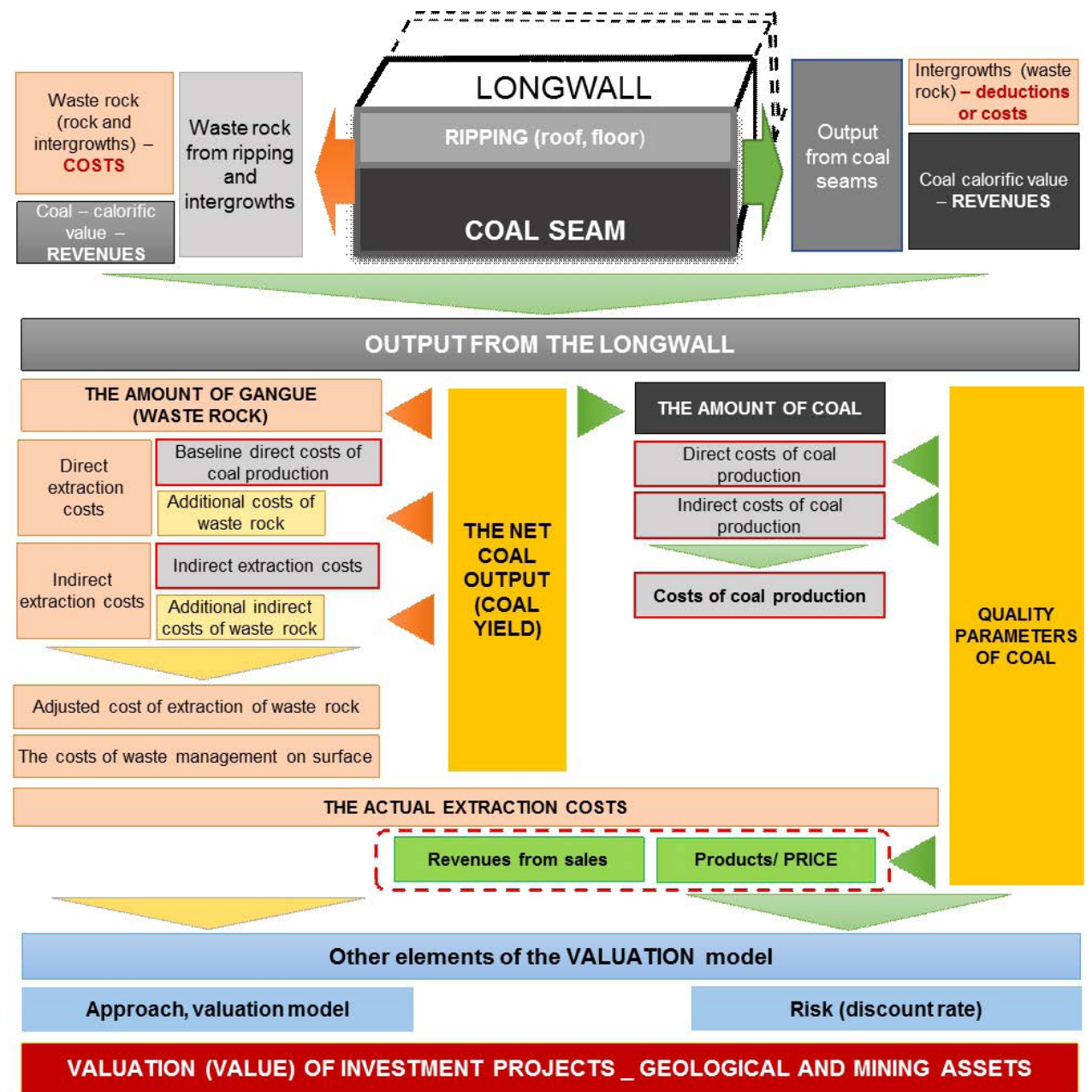

Fig. 1. An integrated approach to assessing the impact of qualitative parameters and coal output on the value of investment projects (geological and mining assets) in the mining industry Source: own study

Rys. 1. Zintegrowane podejście do oceny wpływu parametrów jakościowych i uzysku węgla na wartość przedsięwzięć inwestycyjnych (AGG) w górnictwie

Decomposition of output from the longwall, accompanied by separation of gangue and coal and assigning the corresponding costs, are an important element of the proposed research method. The assumed isolation of both direct and indirect additional costs, related to the mining of gangue, allows for more precise estimation of costs of subsequent processes both in and outside the longwall face. In particular, this applies to horizontal and vertical transportation costs, as well as processing costs. Waste rock has a higher bulk density than coal; for example, transportation of the same volume is the reason for higher loads and energy consumption. Under certain circumstances, rolling costs may increase the cost of 
gangue mining and reduce the cost of clean-coal mining, while the balance of the total costs incurred remains the same. However, this requires realignment of base coal and gangue extraction costs.

The evaluated quality parameters include the calorific value of coal, ash content and sulfur content. The influence of other parameters of extracted coal was omitted, considering them to be insignificant. The calorific value, ash and sulfur of coal are important parameters occurring in the deposit. The aforementioned parameters are crucial for its quality and selling prices.

Waste rock accompanies the process of coal mining without creating added value; it is only a source of costs and operational problems. The amount of gangue is the result of the applied extraction system and specified technical and organizational conditions found in the coal deposit.

The parameter linking the relation between the amount of extracted coal and the gross output is the coal output (in simulations, it is defined as the net coal output or coal yield).

Selected decision parameters were analyzed in their natural range of variation, similar to the expected, that is in deposits, while the calculations were made using simulation procedures

\subsubsection{Study on the impact of coal quality parameters on total revenues}

The quality parameters of coal affect the achievable revenues. The higher the calorific value of coal and the lower ash and sulfur content, the higher the potential price of coal products.

In order to establish the influence of the analyzed coal quality parameters on the value of achievable revenues, a pricing formula, the mathematical formulation of which is expressed in equation No. 1, was applied. This is a classic formula based on the constant energy value in coal, which means that the price of $1 \mathrm{Mg}$ of coal with a higher calorific value should be adjusted upwards (Lorenz et al. 2002).

A feature of the proposed structure is also a fact that it favors the calorific value impact on the development of the real price of coal, while the impact of other parameters is relatively small. This is in line with current trends in transactions between mining companies and power plants. This is also confirmed by the results of simulation studies.

$$
P_{r z}=P_{b} \cdot \frac{Q_{r z}}{Q_{b}}-w_{s} \cdot\left(S_{r z}-S_{b}\right)-w_{a} \cdot\left(A_{r z}-A_{b}\right)
$$

$\Leftrightarrow P_{r z}-$ calculated sales price $[\mathrm{PLN} / \mathrm{Mg}]$,

$P_{b}-$ the base price $[\mathrm{PLN} / \mathrm{Mg}]$,

$Q_{r z}-$ calorific value of coal in the deposit $[\mathrm{GJ} / \mathrm{Mg}]$,

$Q_{b}$ - the calorific value of reference coal, $21 \mathrm{GJ} / \mathrm{Mg}$,

$S_{r z}-$ sulphur content in coal, deposit [\%], 
$S_{b} \quad-\quad$ sulphur content in reference coal, $1.15 \%$,

$A_{r z} \quad-$ ash content in coal, deposit [\%],

$A_{b} \quad-$ ash content in reference coal, $22.0 \%$,

$w_{s}, w_{a}-$ correction coefficients, including corresponding environmental costs of combustion and storage of waste resulting from $1 \mathrm{Mg}$ of coal $\left(w_{s}=11.0 ; w_{a}=0.4\right)($ Grudziński 2009).

The formula used in the valuation model, which allows for the estimation of the expected change in revenues in relation to baseline revenues is expressed by equation No. 2 .

$$
d R_{(Q, S, A)}=\frac{\sum_{i=0}^{i=29}\left(R_{i}-R_{b}\right)}{\sum_{i=0}^{i=29} R_{b}}
$$

$\leftrightarrow d R_{(Q, S, A)}-$ relative change in the expected revenue compared to baseline revenues $[\%]$,

$R_{b} \quad-$ baseline revenues [thousand USD],

$R_{i} \quad-$ expected revenue [thousand PLN],

$Q_{i} \quad-$ expected calorific value of coal; $Q_{i} \in(15 ; 31)[\mathrm{GJ} / \mathrm{Mg}]$,

$S_{i} \quad-$ expected sulphur content in coal; $S_{i} \in(0.7 ; 1.8)[\%]$,

$A_{i} \quad-$ expected ash content; $A_{i} \in(15 ; 40)[\%]$,

$i \quad-$ analysis periods, $i=0,1,2, \ldots, 29$.

2.1.2. Study on the impact of waste rock on the value of the total costs of extraction

Gangue is usually not sold and hence only generates costs. It also negatively affects the rhythm of extraction, transport processes, coal processing and requires storage on the surface, or export outside the mine.

Potential sources of waste rock include:

- ripping from roof and floor,

- intergrowths in coal deposits,

- roof subsidence.

Another major source of waste rock in mines includes longwall workings. This particularly applies to opening-out headings, where the amount of stone can vary from a few to several dozen percent.

The simulation tests, combining the production costs per unit with the net coal output (coal yield), were used to study the impact of variable quantities of gangue.

The net coal output (coal yield) is most commonly understood as the ratio between the amount of clean coal (including intergrowths of up to $5 \mathrm{~cm}$ ) and the amount of coal output 
(gross), including waste rock. It is expressed as a percentage value, usually in the range between $55.0-80.0 \%$. The higher the coal output, the lower the amount of mined gangue and vice versa.

The net coal output depends on the deposit thickness and exploitation depth, which, in turn, results from the extraction technology used. The categories corresponding to the aforementioned term are the output (of mineral) and contamination (Glapa and Korzeniowski 2005).

In order to verify the impact of a variable amount of waste rock on the level of total extraction costs and the value of geological and mining assets, two copyright formulas for estimating fixed and variable operating costs were introduced to the model.

The design of formulas No. 3 and 4 is based on observations of variability of operating costs in longwall faces, where highly varied deposit thickness forced various mining methods.

The formula for estimating fixed costs:

$$
U C f=U C f_{b} \cdot \frac{C Y_{b}}{\left(C Y_{i} \cdot \operatorname{Coe} C f\right)}
$$

The formula for estimating variable costs:

$$
U C v=U C v_{b} \cdot\left[\left(C Y_{b}-C Y_{i}\right) \cdot \operatorname{Coe} C v+1\right]
$$

$$
\begin{array}{ll}
\qquad C_{f} & - \text { unit fixed costs (expected) }[\mathrm{PLN} / \mathrm{Mg}], \\
U C_{f b} & - \text { unit fixed costs (baseline) [PLN/Mg], } \\
U C_{v} & - \text { unit variable costs (expected) [PLN/Mg], } \\
U C_{v b} & - \text { unit variable costs (baseline) [PLN/Mg], } \\
C Y_{b} & - \text { net coal output (coal yield) (baseline) [\%], } \\
C Y_{i} & - \text { net coal output (coal yield) (simulated) [\%], } \\
\text { CoeCf } & - \text { coefficient of elasticity of fixed costs compared to net coal output, } \\
\text { CoeCv } & - \text { coefficient of elasticity of variable costs compared to net coal output. }
\end{array}
$$

As can be seen, fixed unit costs in the first formula are expressed as a quotient of two net coal coefficients, while the potential, variable fixed $\operatorname{cost}^{2}$ is approximated (Begg et al. 2003). The denominator of formula No. 3 is the coefficient of elasticity of fixed costs in relation to coal output. The decrease in the value of the denominator in the above discussed formula results in a more than proportional increase in fixed costs per unit for all values below the baseline net coal output and a less than proportional decrease in unit costs for higher values (Fig. 2).

\footnotetext{
2 It is generally accepted that fixed costs in the mining industry should increase/decrease along with changes in the output or mining model. In practice, the distinction between fixed and variable costs is arbitrary and may vary among mines. Classic literature distinguishes fixed and variable costs, additionally dividing fixed costs into absolutely fixed costs and incrementally fixed costs.
} 
The assumed nonlinear and more than proportional increase in fixed costs for the coal output net below the baseline results from the belief that a significant decrease in the net coal output (coal yield) will:

- significantly delay longwall operations

- result in the increase of expenses related to mining waste rock (rocks harder than coal, increased resistance)

- contribute to the increased number of serious accidents and increased incidence of minor crashes, generating costs and shortening the effective working time, which translates into lower production at a given period of time

In some cases, there is a need for new departments in order to achieve the assumed production objectives. This results in a rapid increase in both costs and expenses (purchases of additional equipment).

The coefficient of cost elasticity compared to net coal output (coal yield) allows for the adjustment for the effect of net coal output change on the level of target costs (fixed, variables) taking into account different empirical data or expert opinion. Its value may fluctuate in the $(-\infty,+\infty)$ interval and belongs to the set of real numbers.

Meanwhile, formula No. 4 allows for the estimation of the expected value of variable costs as the difference between two coefficients of net coal output. When the coefficient of elasticity of fixed costs equals 1, the formula corrects the increase/decrease in variable

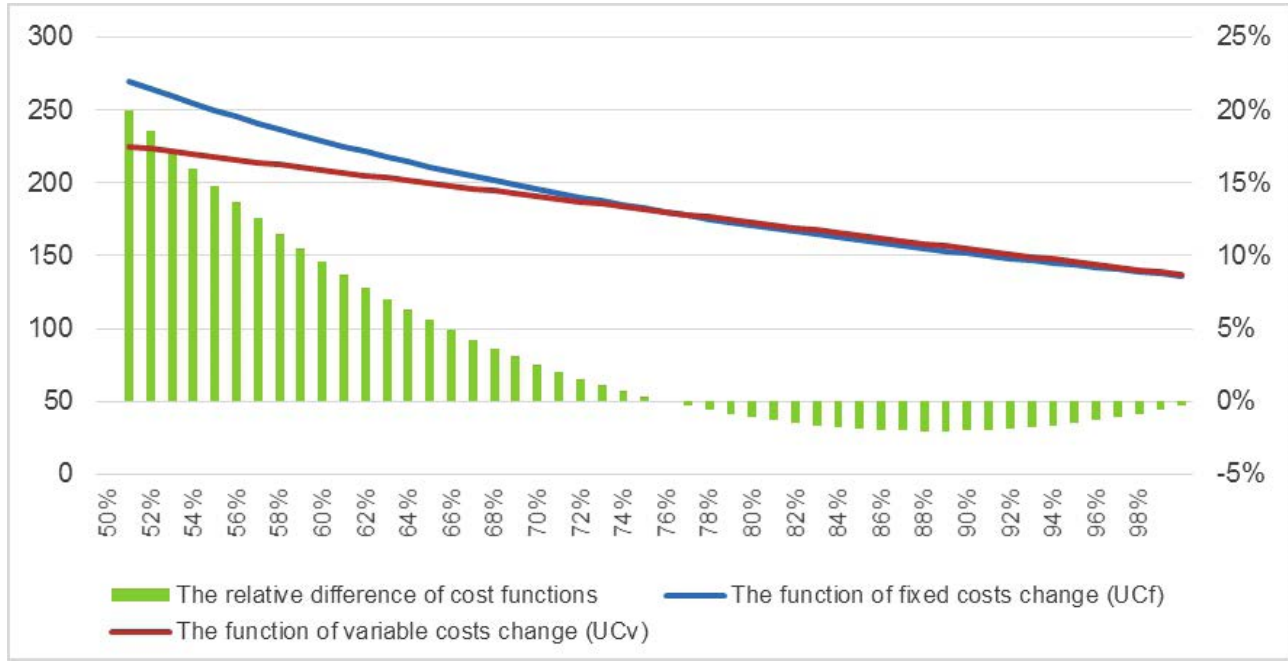

Fig. 2. Graphical presentation of fixed and variable costs changes as a function of net coal output (coal yield). Baseline coal output, against which deviation was measured (estimated), amounts to $75 \%$. Baseline level of costs is 100 units. UCf, UCv - unit fixed or variable cost, respectively Source: own study

Rys. 2. Graficzna prezentacja zmienności kosztów stałych i zmiennych w funkcji współczynnika uzysku węgla netto. Uzysk bazowy węgla, względem którego szacowano odchylenia, wynosi $75 \%$.

Poziom bazowy kosztów 100j. JKs, JKz - odpowiednio koszty (stałe, zmienne) w ujęciu jednostkowym 
costs accompanied by the increase/decrease in net coal output (coal yield) in a linear manner (Figure 2 - the red line). The change of the coefficient of elasticity of variable costs results in up/down deviations from the linear course of function, though the impact of these adjustments is not as strong as in the case of fixed costs.

In Figure 2, the relative difference of function values is highlighted in green. This difference in the analyzed case ranges from $-3 \%$ to $+19 \%$ and is the highest for the lowest values of net coal output (coal yield).

It should be stressed that the introduction of both formulas is not decisive in assessing the impact of waste rock (variability of net coal output) on the level of costs (fixed, variable). Furthermore, it does not necessarily have to correctly reproduce the actual cost variation in hard coal mines compared to the percentage change of net coal output (coal yield). However, for research purposes aimed at a mutual relationship between the values of subsequent cost estimates and changing levels of decision parameters, it remains adequate.

Total operating costs are the sum of fixed and variable costs, which are the product of the unit cost and the assumed level of coal production.

In turn, the formulas No. 5 and 6 allowed for the estimation of the relative percentage share of both baseline and projected cost (fixed, variable) differences using the simulation procedure for the values of the net coal output (coal yield) in the range between $50 \%$ and $99 \%$

$$
\begin{aligned}
d C f_{(\text {Coal_yield })}=\frac{\sum_{i=0}^{i=29}\left(C f_{i}-C f_{b}\right)}{\sum_{i=0}^{i=29} C f_{b}} \\
d C v_{(\text {coal_yield })}=\frac{\sum_{i=0}^{i=29}\left(C v_{i}-C v_{b}\right)}{\sum_{i=0}^{i=29} C v_{b}}
\end{aligned}
$$

$\stackrel{\mapsto}{\Rightarrow} d C f_{(U W N)}, d C v_{(U W N)}$ - relative variation of expected costs (fixed, variable) compared to baseline costs (fixed, variable) [\%],

$C f_{b}, C v_{b}$ - the value of baseline costs (fixed, variable) [thousand PLN],

$C f_{i}, C v_{i}$ - the value of expected costs (fixed, variable) [thousand PLN],

Coal yield $\in(50 ; 99)[\%]$,

$i \quad-$ analysis periods, $i=0,1,2, \ldots, 29$.

Finally, by using formulas No. 3 and 4, the effects of variable levels of contamination of the output on the total costs of coal output were verified. 


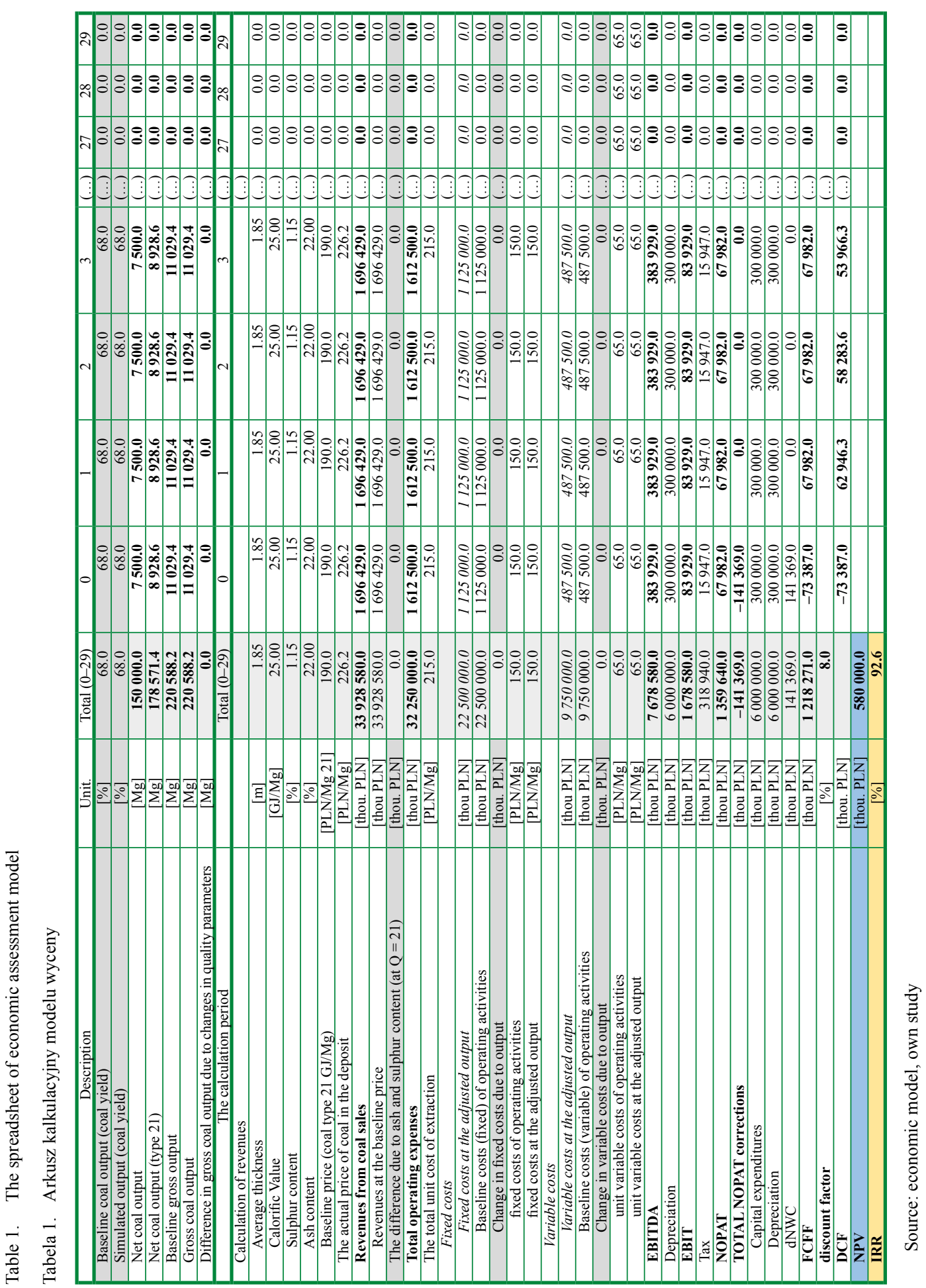




\subsection{The discount pricing model}

The impact assessment of key decision parameters values was performed using a dedicated model based on the discount approach. The construction of the cash flow statement was modeled after the approach based on free cash flow to firm (FCFF).

The construction of the cash flow statement was accompanied by the principle of maximum transparency of calculations and test results obtained. Therefore, in the constructed discount model, the value assessment of analyzed deposits was carried out only for the operational phase lasting up to 30 consecutive periods.

The level of average annual capital expenditures was made dependent on extraction level and was offset in the NPV method by depreciation of the same annual value.

The need for additional capital has not been calculated; hence the impact of interest on financial results has been omitted.

Change in the demand for net working capital has been taken into account when assuming equal equality liabilities and short-term receivables cycles, with financial stocks calculated as the equivalent of $1 / 12$ of annual sales.

The discount rate was set at a fixed level of $8.0 \%$, equally in all 3 scenarios.

What is more, the provisions for the Mine Decommissioning Fund are not included in the calculations, while the profit before interest and tax was charged only with income tax (19.0\%) on EBIT (earnings before deducting interest and taxes).

A screenshot of a part of the sheet model is presented in Table 1. The tested lines are highlighted in gray.

\section{The results of the analysis}

Since the simulation tests revealed the dependence of the obtained results on several key decision variables:

- baseline output,

analysis period,

- target production level,

- the amount of operational reserves (resource base),

- baseline price and quality parameters in the pricing formula,

- flexibility of fixed and variable costs function parameters,

- the share of fixed and variable costs in the cost of extraction,

$\rightarrow$ discount rate,

the complexity of the scope and results of the research was reduced to three scenarios:

- baseline - representing the model of a typical mine extracting coal with average quality parameters at current market prices of reference coal,

- low - representing the model of a small mine extracting coal with unfavorable quality parameters at prices similar to current market prices of reference coal, 
- high - representing the model of a large mine extracting coal with good or very good quality parameters at current market prices of reference coal.

The introduction of an additional two scenarios (low and high) finally allowed for the presentation of the results of analyses in a wide range of decision variables analyzed. The obtained results are between the pessimistic (low), and optimistic (high) scenarios. Therefore, taking into account the limitations of this analysis (impact of only one decision parameter studied at one time), it can be expected that they actually reflect the scale of the analyzed problem.

However, it should be emphasized that correlated changes of several decision-making parameters can occur at one time (simultaneously). Some of these changes may increase the analyzed effects while the others might reduce the impact of individual decision making variables on the valuation process of geological and mining projects.

\subsection{Key assumptions and results of the assessment in the baseline scenario}

The most important assumptions for the baseline scenario are summarized below:

- Net coal output: $68.0 \%$,

- Coal quality parameters: $\mathrm{Q}=25 \mathrm{GJ} / \mathrm{Mg}, \mathrm{A}=22 \%, \mathrm{~S}=1.15 \%$,

- Analysis period: 20 years,

- Target production level: 7,5 million Mg per year,

- Amount of operational reserves (resource base): 150 million Mg,

- Flexibility of fixed and variable costs in relation to net coal output: ICERs, ICERz $=1$,

- the share of fixed: $70 \%$, and variable costs: $30 \%$,

- Cash cost of production: 215.0 PLN/Mg,

- The price of reference coal 190.0 PLN/Mg of calorific value: 21 GJ.

The assessment of the impact of the variability of coal quality parameters on the total amount of revenues and the resulting NPV for the baseline scenario is summarized in Table 2 (2a, 2b, 2c).

Meanwhile, the results of the assessment of the impact of variable amounts of waste rock on total costs and the resulting NPV in the baseline scenario are shown in Table $2 \mathrm{~d}$.

A graphical representation of the variability of revenues, operating costs and the resulting NPV for the baseline scenario is presented in Figure 3. 


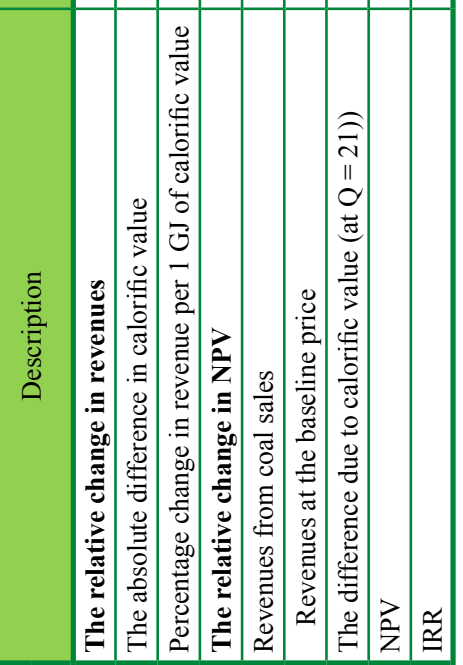




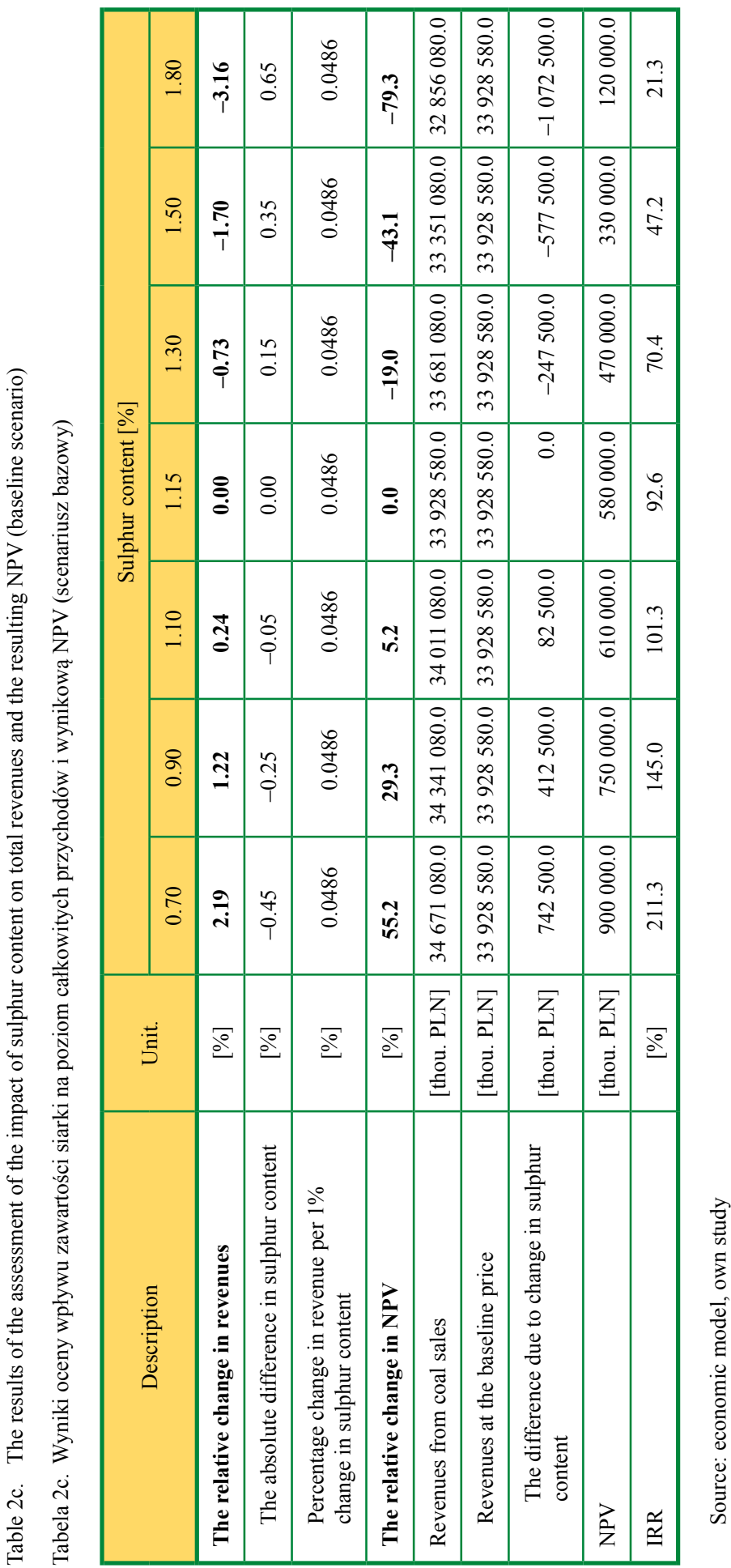




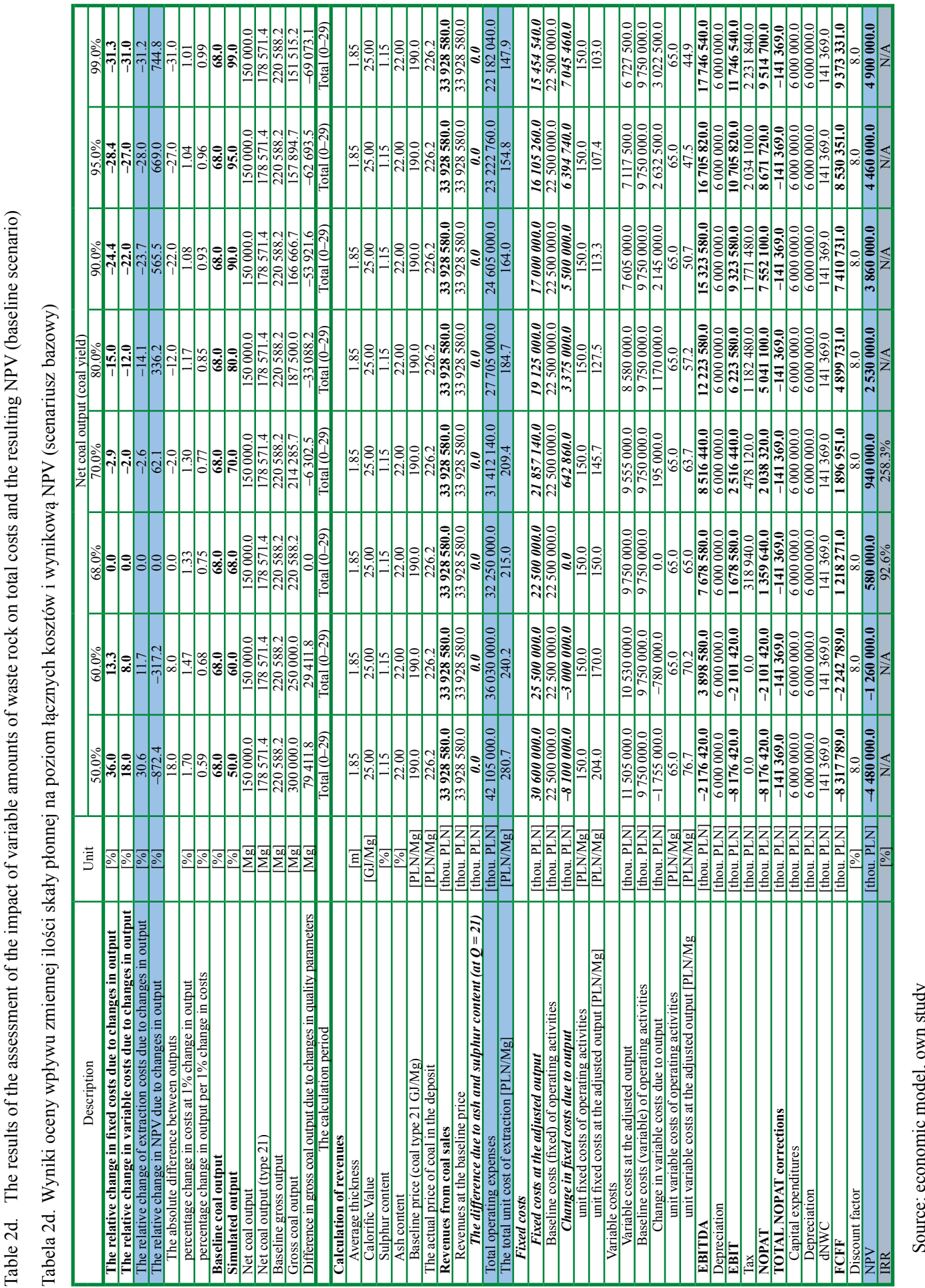



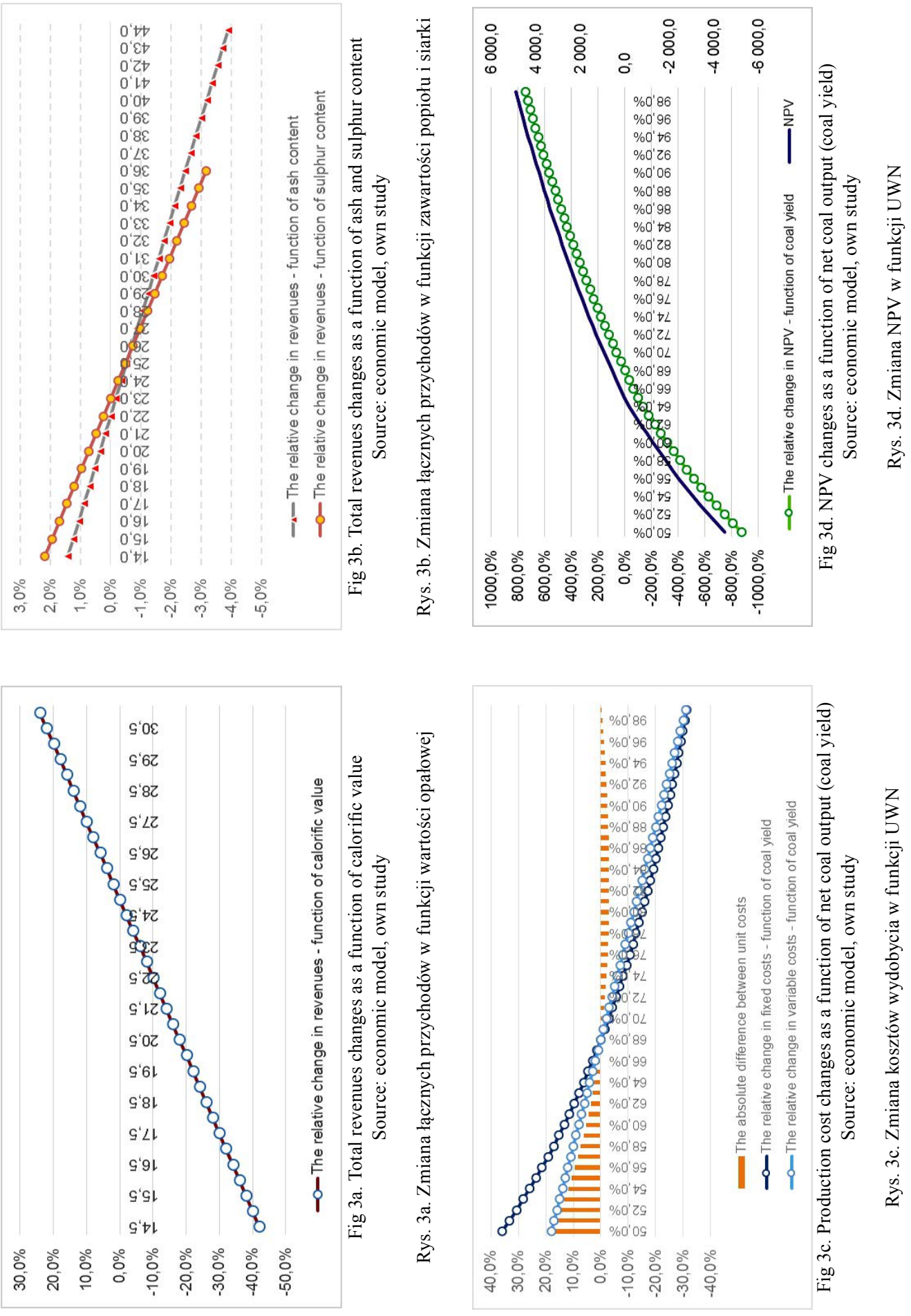


\subsection{Key assumptions and the results}

of the assessment for low and high scenario

Table 3 summarizes the key assumptions for the low and high scenarios.

Table 3. Key assumptions for the low and high scenarios in the assessment model

Tabela 3. Kluczowe założenia dla scenariusza niskiego i wysokiego w modelu wyceny

\begin{tabular}{|c|c|c|c|c|}
\hline Description & Low scenario & \multicolumn{3}{|c|}{ High scenario } \\
\hline Baseline Net coal output: $60.0 \%$ & $60 \%$ & \multicolumn{3}{|c|}{$75 \%$} \\
\hline Coal quality parameters & $\begin{array}{c}\mathrm{Q}=21 \mathrm{GJ} / \mathrm{Mg}, \mathrm{A}=22 \%, \\
\mathrm{~S}=1.15 \%\end{array}$ & \multicolumn{3}{|c|}{$\begin{array}{c}\mathrm{Q}=21 \mathrm{GJ} / \mathrm{Mg}, \mathrm{A}=22 \% \\
\mathrm{~S}=1.15 \%\end{array}$} \\
\hline Analysis period & 30 years & \multicolumn{3}{|c|}{30 years } \\
\hline Target production level & 5.0 million $\mathrm{Mg}$ per year & \multicolumn{3}{|c|}{10.0 million $\mathrm{Mg}$ per year } \\
\hline $\begin{array}{l}\text { The amount of operational reserves } \\
\text { (resource base) }\end{array}$ & 150 million $\mathrm{Mg}$ & \multicolumn{3}{|c|}{300 million $\mathrm{Mg}$} \\
\hline \multirow{4}{*}{$\begin{array}{l}\text { Flexibility of fixed and variable costs } \\
\text { in relation to net coal output }\end{array}$} & \multirow{4}{*}{ ICERs, ICERz = 1; } & Description & ICERs & ICERz \\
\hline & & $\mathrm{NCO}<60 \%$ & 0.86 & 1.25 \\
\hline & & $60<\mathrm{NCO}<75 \%$ & 1.12 & 0.90 \\
\hline & & $\mathrm{NCO}>750 \%$ & 1.20 & 1.50 \\
\hline The share of costs & fixed: $50 \%$, variable: 50 & \multicolumn{3}{|c|}{ fixed: $80 \%$, variable: $20 \%$} \\
\hline Cash cost of production: $270 \mathrm{PLN} / \mathrm{Mg}$ & $270 \mathrm{PLN} / \mathrm{Mg}$ & \multicolumn{3}{|c|}{170 PLN/Mg } \\
\hline The price of reference coal $190 \mathrm{PLN} / \mathrm{Mg}$ & $190 \mathrm{PLN} / \mathrm{Mg}$ & \multicolumn{3}{|c|}{190 PLN/Mg } \\
\hline
\end{tabular}

The assessment of the impact of calorific value on total revenues and the resulting NPV is summarized in Table 4 (4a, 4b, 4c).

The results of the assessment of the impact of variable amounts of waste rock on total costs and the resulting NPV in low scenario are summarized in Table $4 \mathrm{~d}$.

The assessment of the impact of coal quality parameters on total revenues and the resulting NPV for high scenario is summarized in Table 5 (5a, 5b and 5c).

The results of the assessment of the impact of geological and mining parameters on total costs and the resulting NPV are presented in Table 5d. 

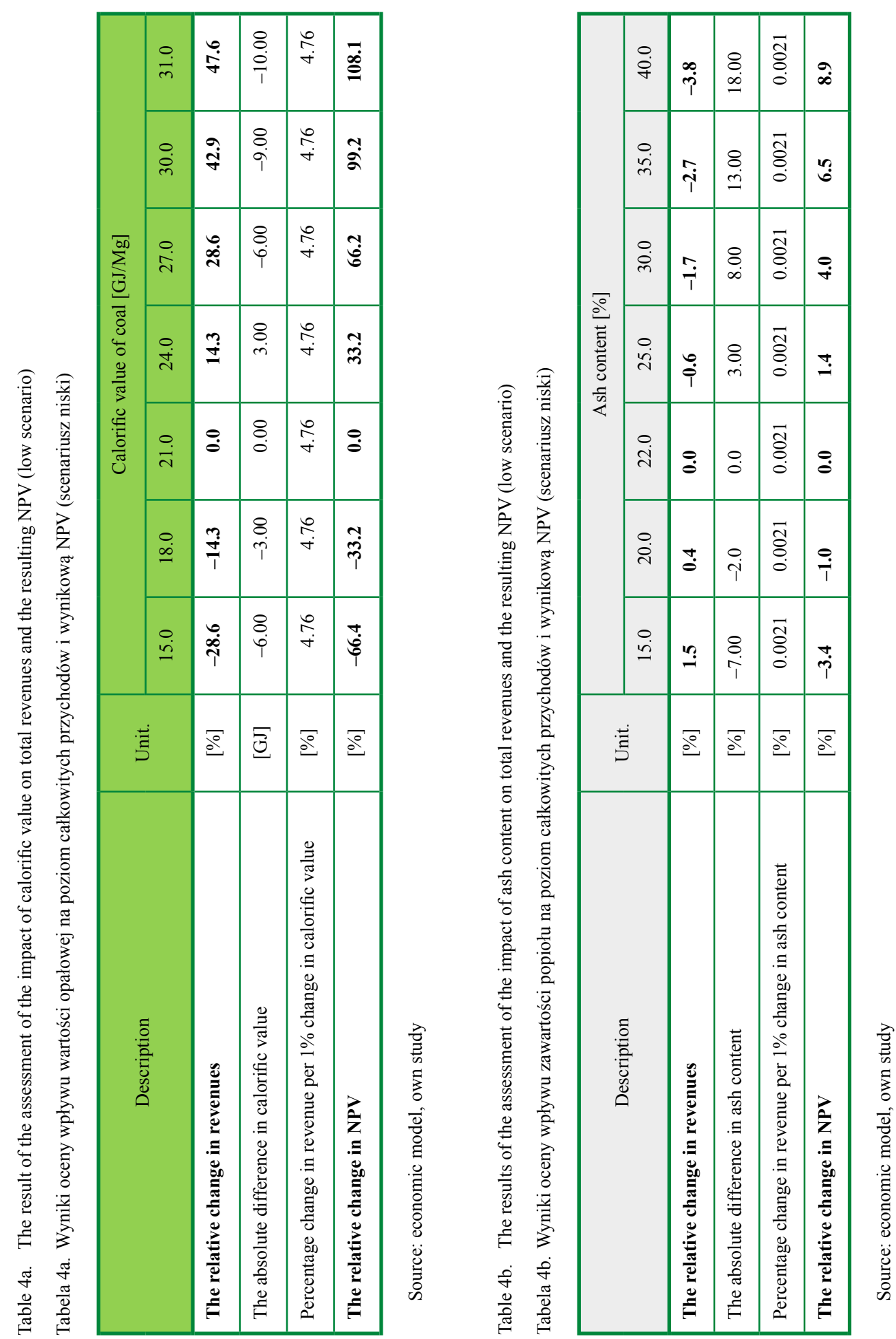

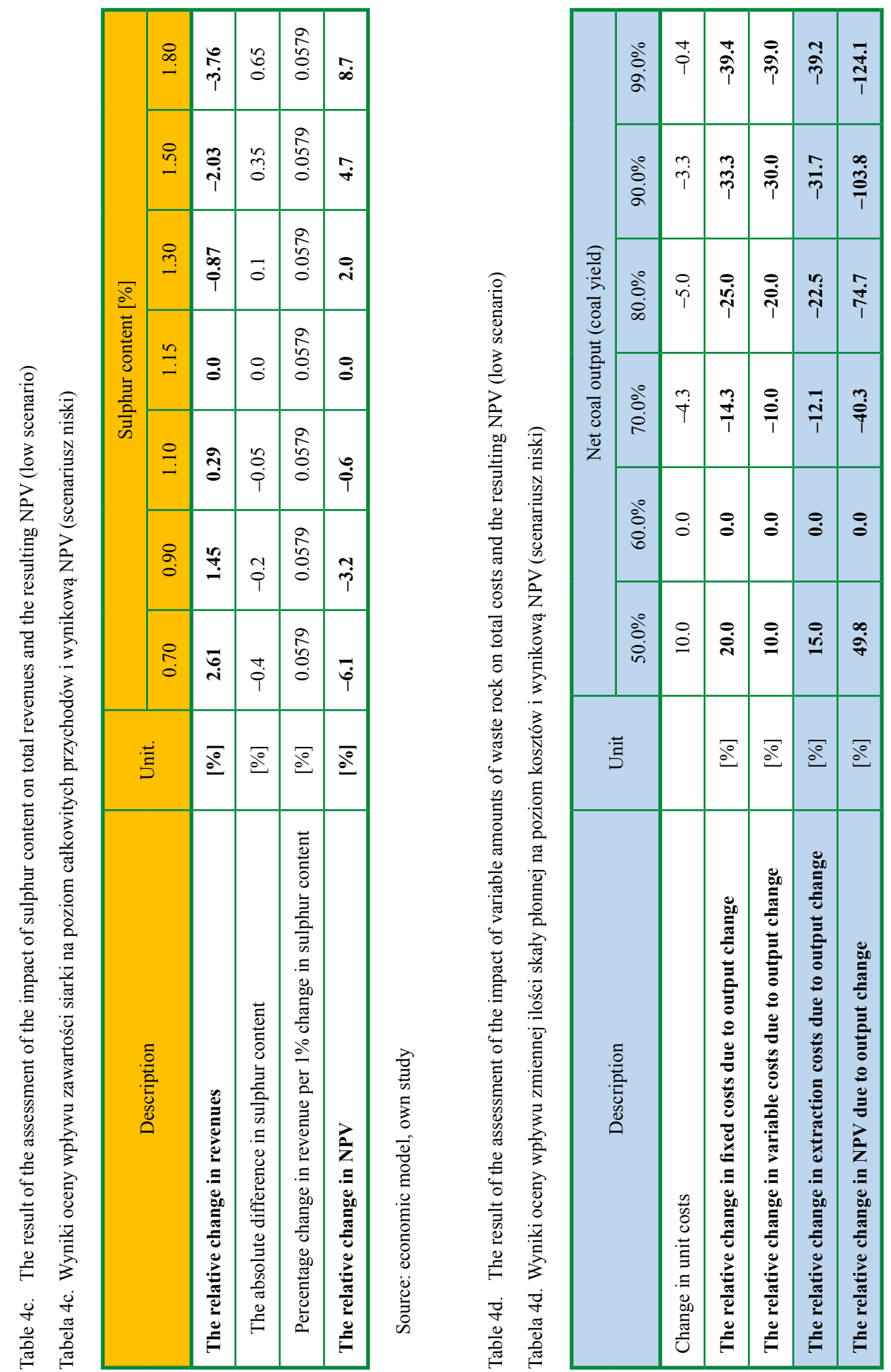

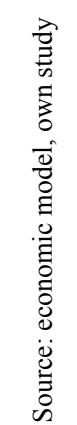



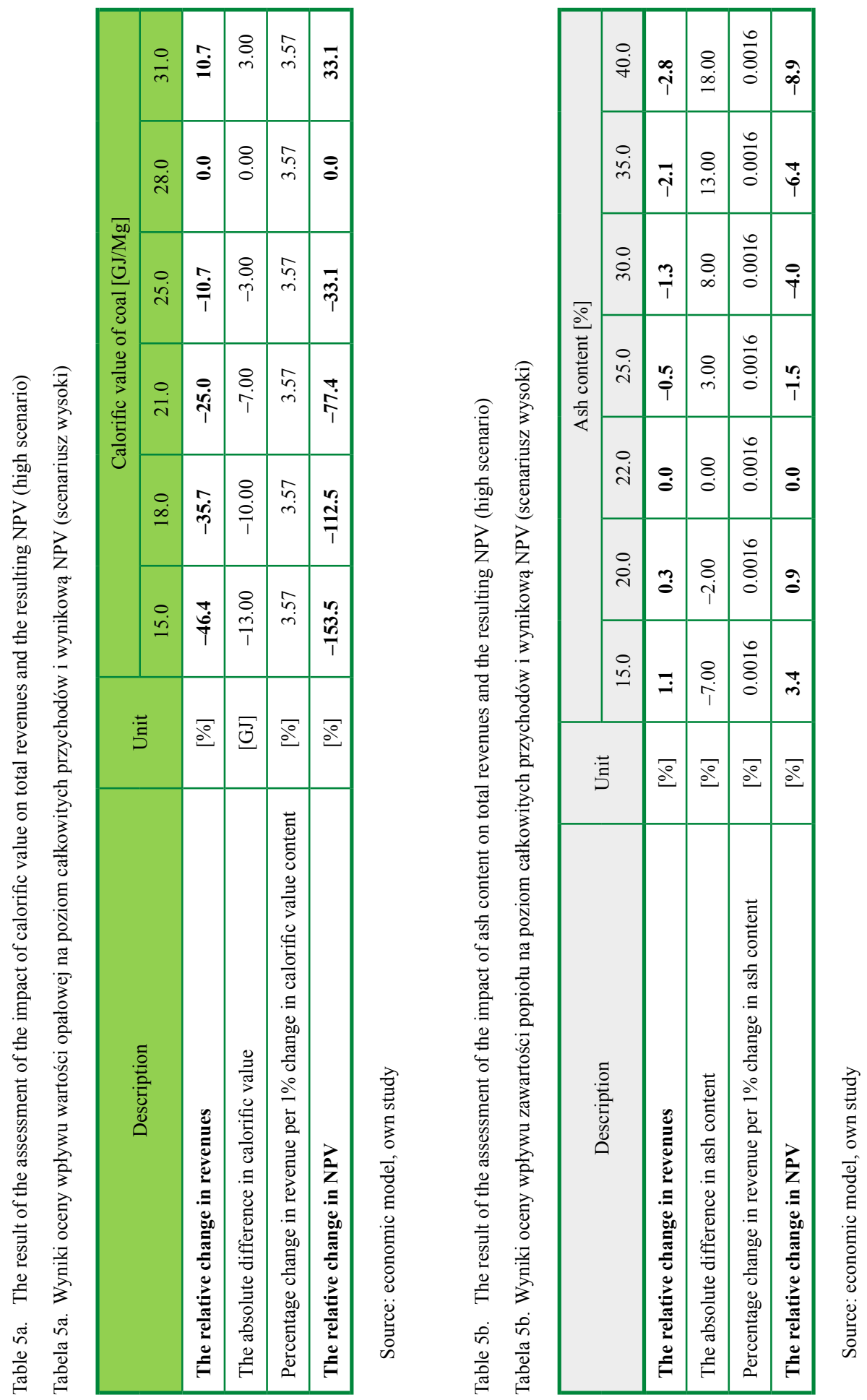

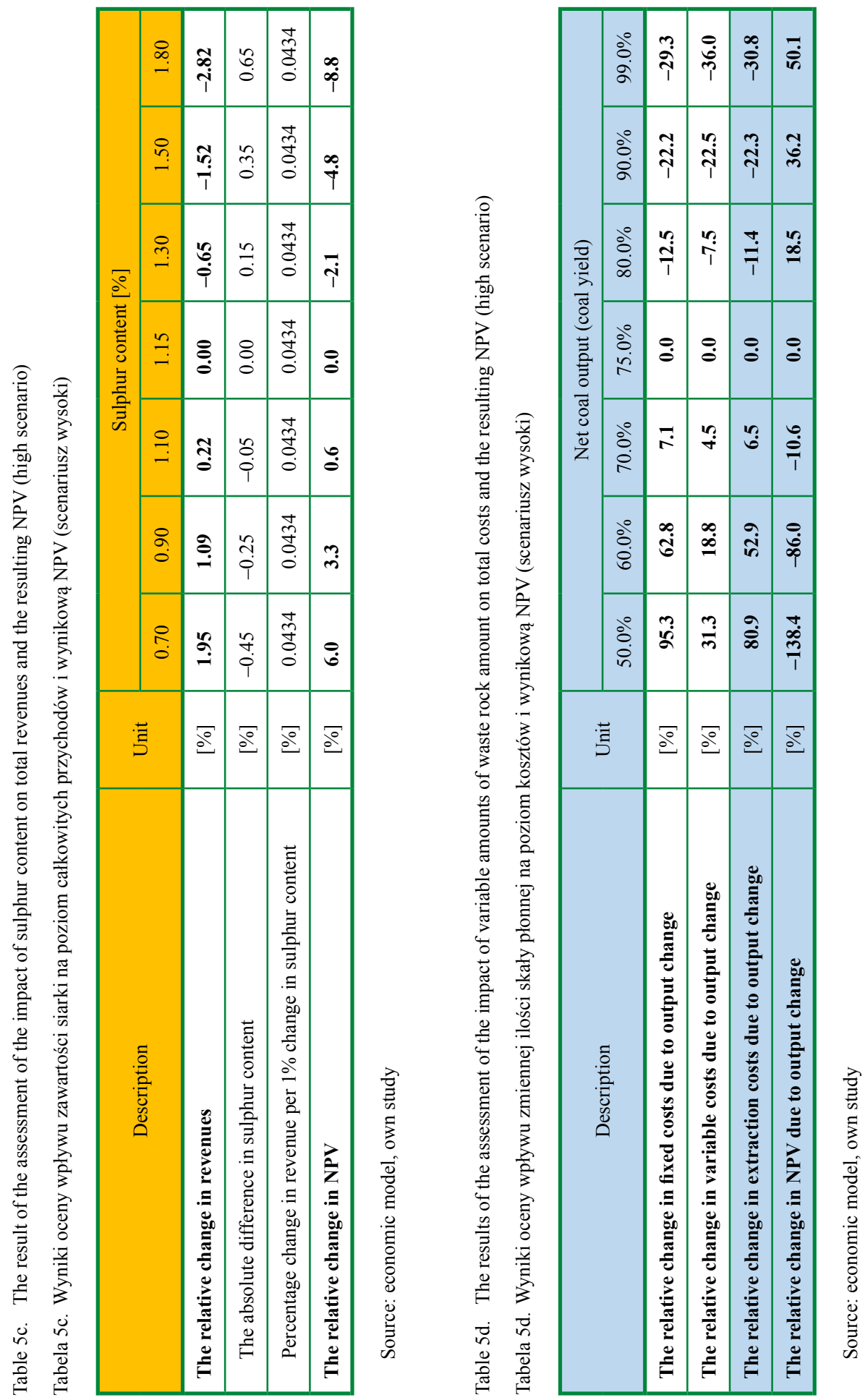


\section{Evaluation of the results and conclusions}

Given the obtained results of the impact assessment of the quality parameters and net coal output (coal yield) on the level and variability of total revenues, costs and valuation, the following conclusions can be drawn:

1. The calorific value has a strong influence on total revenues. It is the highest in the low scenario: for example, the decrease of calorific value by $6 \mathrm{GJ} / \mathrm{Mg}$ results in a nearly $28.6 \%$ decline in total revenues over the next 30 years and a nearly $66.4 \%$ decrease in NPV (Table 4a).

- The impact of the calorific value on total revenues is most visible in the low scenario with a nearly $4.76 \%$ change in total revenues per $1 \mathrm{GJ}$ change in calorific value. This impact ranges from $3.57 \%$ - high scenario to $4.76 \%$ - low scenario in all 3 scenarios.

- However, the net present value in the baseline scenario varies significantly (Table 2a). An over $1201.0 \%$ change in the NPV with a decrease in calorific value of $10 \mathrm{GJ}$ (a decrease of $40.0 \%$ ) results from the conditions of the baseline scenario, where the calculated NPV is relatively close to 0 .

2. The impact of ash and sulphur content on the value of total sales revenue is practically negligible. As can be seen in tables $(2 \mathrm{~b}-\mathrm{c}, \mathrm{c}-4 \mathrm{~b}, 5 \mathrm{~b}-\mathrm{c})$, the impact of sulphur and ash content is comparable and does not exceed $3.80 \%$ (low scenario), given the increase in ash content by $82.0 \%$ (from $220 \%$ up to $40.0 \%$ ) and sulphur content by over $36.1 \%$ (from $1.15 \%$ to $1.8 \%$ ).

- The impact of ash and sulphur is limited by the formula used in the calculation. When it comes to coal processing, both ash and sulphur content can be effectively reduced, which is reflected in the operating costs of coal processing.

3. The amount of waste rock can significantly affect the value and variability of the total extraction costs and thus the resulting NPV. The highest variability in extraction costs (up to $81.0 \%$ with a decrease in the net coal output from $75.0 \%$ to $50.0 \%$ ) is in the high scenario (Table. 5d), where the formulas for estimating fixed and variable costs include the additional corrections of the flexibility of costs in relation to the net coal output.

- The impact of gangue on the value and variability of the total extraction costs is not a linear function. Approximating the actual costs of extraction with the use of formulas No. 3 and 4, the highest variations in costs and valuation should be in the range of low values of the net coal output.

- The relative change in the NPV is the highest in the baseline scenario, with an $18 \%$ decrease in the net coal output (coal yield) resulting in the increase of total extraction costs by nearly $30.6 \%$ and the decrease of Net Present Value by $872.4 \%$ (Table 2d). The above average sensitivity of NPV, as in the case of the impact of calorific value, is due to the conditions of the baseline scenario. 
The practical importance of the obtained results is also emphasized by the following observations:

- For calorific value in the range of $21-27 \mathrm{GJ} / \mathrm{Mg}$, the expected variability of revenues from coal sales (with fixed baseline price of 190 PLN per $1 \mathrm{Mg}$ of steam coal with calorific value of $21 \mathrm{GJ}$ ) ranges from $20.0 \%$ to $29.0 \%$, respectively. However, the NPV estimation error is in the range of $0.0-78.0 \%$.

- In the case of hard coal deposits, where the actual coal output can be in the range of $60.0-80.0 \%$, a change in extraction costs by as much as $53.0 \%$ can be expected. Such a situation may apply in the case of twin deposits of limited thickness, as they can rely on coal extraction costs from medium and thick coal seams.

\section{Summary and conclusions}

The paper presents an assessment of the direction and strength of the influence of key quality parameters of coal and gangue on the value of geological and mining projects. This is an issue of particular interest, especially given the current crisis of hard coal mining in Poland.

The presented range of tests and results is important in the case of valuation of new geological and mining assets or updating financial projections for coal mines planning to undertake mining activities in relatively different geological and mining conditions.

The research has shown that both revenues and costs can significantly vary depending on the assumptions on the quality of coal or the amount of gangue. In particular, the net coal output can be a good meter of expected trends when it comes to the costs of mining activities.

The paper has not fully addressed the issue of the impact assessment of other factors related to the deposit and mining technology on the value and variability of revenues, expenses or ultimately the value of investment projects in coal mining. The issue of the impact of the analyzed variables on the assessment of the active mines and hard coal deposits value has not been unequivocally settled. However, the paper points to the importance of the issues analyzed in this area.

The question of valuation of mining and geological assets or economic risks associated with extracting resources is further intensified by the degree of deposit exploration (prospecting), geographical distance of reference deposits, the diversity of geological and mining conditions, deposit's depth, tectonic diversity or deposit depletion resulting from prior exploitation. These features, however, are difficult to measure even though their impact, in extreme cases, can completely rule out the chances for a profitable exploitation.

The study emphasizes the broad context of the issues discussed and the difficulty of presenting them with use of the discount approach and scenario analysis only. There is a need for other studies focusing on mathematical modeling using stochastic simulation, in order to assess the impact of several correlated parameters on the value of investment projects at the same time. 
The presented paper is a part of a larger work on guidelines allowing for the proper valuation of geological and mining assets taking into account additional estimation errors of average values of quality parameters of extracted minerals. The research should be supplemented by the selection of the appropriate discount rate (a well-studied topic in the literature) taking into account additional uncertainties and risks.

\section{REFERENCES}

Begg et al. 2003 - Begg, D., Fischer, S. and Dornbusch, R. Microeconomics, Warszawa: Wyd. PWE.

Brealey, R.A. and Myers, S.C. 2001. Principles of Corporate Finance, 6th edition. New York: McGraw-Hill.

Brzychczy, E. 2012. Metoda modelowania i optymalizacji robót eksploatacyjnych w wielozakładowym przedsiębiorstwie górniczym. Kraków (The method of modeling and optimization of mining operations of a multi-mining enterprise): Wydawnictwa AGH. Seria Rozprawy i Monografie no 245 (in Polish).

Damodaran, A. 2007. Finanse korporacyjne Teoria i praktyka (Corporate Finance: Theory and Practice). Edition II. Onepress.

Fuksa, D. 2013, Koncepcja obliczania wieloasortymentowego progu rentowności dla przedsiębiorstwa górniczego (The concept of determination and analysis of the break-even point for a mining enterprise), Archives of Mining Sciences vol. 58, no 2, pp. 395-410 (in Polish).

Glapa, W. and Korzeniowski, J.I. Mały leksykon górnictwa odkrywkowego.(Small lexicon of opencast mining) [Online] Available at: http://www.kgo.agh.edu.pl/wp-content/uploads/2012/12/mlgo.pdf[Accessed 30.06.2015].

Grudziński, Z. 2009. Propozycje struktur cenowych dla węgla kamiennego energetycznego i węgla brunatnego (Proposals of prize structure for steam hard coal and lignite). Polityka Energetyczna - Energy Policy Journal 12 (2/2), pp. 159-171 (in Polish).

Grudziński, Z. 2012. Metody oceny konkurencyjności krajowego węgla kamiennego do produkcji energii elektrycznej (Methods for evaluating the competitiveness of domestic coal in electricity production). Kraków: IGSMiE PAN. Seria, Studia, Rozprawy i Monografie no. 180 (in Polish).

Jaszczuk, M. and Kania, J. 2008. Składniki kosztów pozyskania węgla i jego cena jako czynniki decyzyjne w ustalaniu wielkości wydobycia (Coal production costs components and coal price as crucial factors in the designation of coal output), Archives of Mining Sciences vol. 53, no 2, pp. 183-214 (in Polish).

Karbownik, A. 1987. Podstawy teorii projektowania. Zagadnienia wybrane dla kierunków górniczych (Fundamentals of design theory. The selected issues for directions mining). Politechnika Śląska. Gliwice 1987 (in Polish).

Kaula, R. and Pielot, J. 2005. Zagadnienia sterowania produkcją w układzie technologicznym procesów przeróbki węgla (Problems of production control in coal preparation technological system), Archives of Mining Sciences vol. 50, no 1, pp. 69-100 (in Polish).

Kopacz, M. 2009. Metoda wyceny projektów inwestycyjnych w polskim górnictwie rudnym z wykorzystaniem symulacji stochastycznej (The method of valuation of investment projects in Polish ore mining with use of stochastic simulation). Kraków: The Mineral and Energy Economy Research Institute of the Polish Academy of Sciences. Seria, Studia, Rozprawy i Monografie no. 159 (in Polish).

Kopacz, M. 2015. Ocena kosztów gospodarki skałą płonną w funkcji zmiennego poziomu współczynnika uzysku węgla netto na przykładzie kopalni węgla kamiennego, Gospodarka Surowcami Mineralnymi-Mineral Resources Management vol. 31, issue 3, pp. 121-144 (in Polish).

Lisowski, A. 2001. Podstawy ekonomicznej efektywności podziemnej eksploatacji złóż (The basics of economic efficiency in underground deposit exploitation). Katowice-Warszawa. Wyd. PWN (in Polish).

Lorenz et al. 2002 - Lorenz, U., Blaschke, W. and Grudziński, Z. Propozycja nowej formuły sprzedażnej węgla energetycznego przeznaczonego dla energetyki zawodowej (Proposal for a new formula of selling steam coal destined for professional power engineering). The Mineral and Energy Economy Research Institute of the Polish Academy of Sciences. Seria, Studia, Rozprawy i Monografie no. 112 (in Polish). 
Lubosik, Z. 2009. Geoinżynieryjne i ekonomiczne kryteria eksploatacji węgla kamiennego z resztkowych parcel pokładów (Geological, mining-technical and economic criteria of extracting residual parts of hard coal seams). Prace Naukowe GIG. Górnictwo i Środowisko, no. 3, 2009 (in Polish).

Magda et al. 2002 - Magda, R., Woźny T. and Kowalczyk B. et al. 2002. Racjonalizacja modelu i wielkości kopalń węgla kamiennego w warunkach gospodarczych początku XXI wieku (Rationalization of coal mine model and size with regard to economic conditions at the beginning of 21 st [twenty first] century), Kraków: wyd. AGH (in Polish)

Ministerstwo Środowiska. Rozporządzenie Ministra Środowiska (The Ministry of the Environment. Regulation of the Minister of the Environment). [Online] Available at: http://web.archive.org/web/20051227032310/http:// www.mos.gov.pl/1akty_prawne/rozporzadzenia_ms/05.128.1075.pdf [Accessed 30.06.2015] (in Polish).

Naworyta W. and Mazurek S., 2010, Zastosowanie parametru cenowego jako wstęp do projektowania zagospodarowania górniczego złóż węgla brunatnego (Utilization of price parameters for lignite deposit exploitation plan), Polityka Energetyczna - Energy Policy Journal v. 13, i. 2, pp. 341-353 (in Polish).

Panfil, M. and Szablewski, A. 2006. Metody wyceny spótki: perspektywa klienta i inwestora (The methods of company valuation: the customer and investor perspective). Warszawa: Wyd. Poltext (in Polish),

Polskie Stowarzyszenie Wyceny Złóż Kopalin. Kodeks Wyceny Złóż Kopalin (Polish Association of Mineral Assets Valuators. The Code of Mineral Assets Valuation). [Online] Available at: http://www.polval.pl/kodekspolval. pdf [Accessed 30.06.2015] (in Polish).

POLVAL 2008, Polskie Stowarzyszenie Wyceny Złóż Kopalin. Kodeks Wyceny Złóż Kopalin (Polish Association of Mineral Assets Valuators. The Code of Mineral Assets Valuation). [Online] Available at: http://www.polval.pl/kodekspolval.pdf [Accessed 30.06.2015] (in Polish).

Przybyła, H. and Chmiela, A. 2007. Organizacja i ekonomika w projektowaniu wybierania wegla (Organisation and economics in designing coal extraction). Gliwice. Wyd. Politechniki Śląskiej (in Polish).

Rajwa, S. 2007. Wpływ wybranych wyników geoinżynieryjnych na proces przygotowania produkcji w polskich kopalniach węgla kamiennego (Impact of selected geoengineering results on the production preparation process in Polish hard coal mines). Katowice. Prace Naukowe GIG. Górnictwo i Środowisko no. 4 (in Polish).

Rogowski, W. 2004. Rachunek efektywność przedsięwzięć inwestycyjnych (Account: the efficiency of investment projects). Kraków: Wyd. Oficyna Ekonomiczna (in Polish).

Saługa, P. 2011. Elastyczność decyzyjna w procesach wyceny projektów geologiczno-górniczych (Managerial flexibility in mineral project valuation). Kraków: The Mineral and Energy Economy Research Institute of the Polish Academy of Sciences. Seria, Studia, Rozprawy i Monografie no. 167 (in Polish).

Sobczyk, E.J. 2009. Uciążliwość geologiczno-górniczych warunków eksploatacji węgla kamiennego i jej wpływ na gospodarkę złożem (The inconvenience from geological and mining conditions of coal mining and its impact on the deposit management). Kraków: The Mineral and Energy Economy Research Institute of the Polish Academy of Sciences. Seria, Studia, Rozprawy i Monografie no. 150 (in Polish).

Turek, M. ed. 2013. Analiza i ocena kosztów w górnictwie węgla kamiennego w Polsce w aspekcie poprawy efektywności wydobycia (Analysis and evaluation of costs in Polish coal mining industry in terms of improving the efficiency of extraction). Warszawa: Difin (in Polish).

Wanielista et al. 2002 - Wanielista, K., Saługa, P. and Kicki, J. 2002. Wycena wartości zasobów złoża: Nowa strategia i metody wyceny (The valuation of deposit resources: New strategy and valuation methods), Kraków: Wyd. IGSMiE PAN, Seria z Lampką Górniczą, 12 (in Polish).

Włodarski, K. and Bijańska, J. 2014. Ocena ekonomicznej efektywności i ryzyka eksploatacji resztkowych złóż węgla kamiennego na wybranym przykładzie (Assessment of economic effectiveness and risk of exploitation of the residual hard coal deposits illustrated with a selected example). Przeglad Górniczy 9, pp. 86-89 (in Polish). 
OCENA WPLYWU PARAMETRÓW JAKOŚCIOWYCH WĘGLA ORAZ SKALY PLONNEJ

NA WARTOŚĆ GÓRNICZYCH PROJEKTÓW INWESTYCYJNYCH - ZLÓŻ WEGLA KAMIENNEGO

\author{
Słowa kluczowe
}

górnictwo węgla kamiennego, aktywa geologiczno-górnicze, wycena, model symulacyjny, przychody, koszty, uzysk węgla, zanieczyszczenie urobku, wartość opałowa, zawartość siarki, zawartość popiołu

\title{
Streszczenie
}

Artykuł stanowi próbę oceny wpływu parametrów geologicznych i górniczych na poziom przychodów, kosztów oraz wartość przedsięwzięć inwestycyjnych w górnictwie węgla kamiennego.

Teza pracy wiąże się z przekonaniem autora, iż w obszar czynników istotnie współokreślających ocenę przychodów, kosztów i efektywność eksploatacji należy wpisać, obok parametrów jakościowych węgla, także uzysk kopaliny.

Pomijanie lub pobieżna ocena parametrów jakościowych węgla w pokładach oraz wpływu uzysku na postęp i koszty wydobycia może istotnie zniekształcać ocenę potencjału konkretnych aktywów geologiczno-górniczych. Dotyczy to w szczególności wydobycia w nowych rejonach wydobywczych lub też nowych złożach.

Do badań symulacyjnych zbudowano dedykowany model oceny pozwalający skwantyfikować kierunek i siłę wpływu wartości opałowej, zawartości popiołu i siarki oraz współczynnika uzysku węgla netto (UWN) na poziom i zmienność łącznych przychodów, kosztów i ostatecznie wartość projektów geologiczno-górniczych. W tym celu opracowano również autorskie formuły szacowania kosztów stałych i zmiennych w funkcji zmiennego UWN.

Rezultaty badań przedstawiono ostatecznie w konwencji analizy scenariuszowej.

Uzyskane wyniki wskazują na istotny wpływ wartości opałowej i ilości skały płonnej mierzonej zmiennością uzysku węgla netto na poziom generowanych przychodów, kosztów oraz prognozowane miary oceny działalności operacyjnej hipotetycznej kopalni węgla kamiennego.

Wykazano, że zmiana o 1 GJ wartości opałowej może powodować od 3,57\% do 4,76\% wzrostu/ /spadku łącznych przychodów. W przypadku złóż węgla kamiennego, dla których realny uzysk węgla może wahać się w przedziale $60-80 \%$ można oczekiwać zmiany kosztów wydobycia węgla nawet o 53,0\% w tym zakresie. Błąd oszacowania NPV, przy zmienności wartości opałowej w przedziale 21-27 GJ/Mg, może wahać się w przedziale 0-78\%, natomiast spadek uzysku węgla o 18 pkt. może obniżać wycenę działalności operacyjnej kopalni nawet o $872,4 \%$, co wynika z cech metody NPV i opracowanego scenariusza bazowego (NPV $\approx 0$ ).

W publikacji nie wyczerpano zakresu analizowanej problematyki. Artykuł stanowi część większej całości prac nad sformułowaniem wytycznych (wskazówek) pozwalających właściwie szacować wartość aktywów geologiczno-górniczych w warunkach zmiennych parametrów geologicznych i górniczych, biorąc pod uwagę dodatkowo błędy oszacowania wartości średnich cech jakościowych wydobywanej kopaliny. 


\title{
THE IMPACT ASSESSMENT OF QUALITY PARAMETERS OF COAL AND WASTE ROCK ON THE VALUE OF MINING INVESTMENT PROJECTS - HARD COAL DEPOSITS
}

\author{
Keywords \\ hard coal mining, mining and geological assets, economics assessment, \\ simulating model, revenues, costs, coal output, output contamination, calorific value, \\ sulphur content, ash content
}

\section{Abstract}

The paper is an attempt to assess the impact of geological and mining parameters on revenues, costs and the value of investment projects in the hard coal mining industry.

The article reflects the author's conviction that the factors significantly determining revenues, costs and effectiveness of exploitation should include, in addition to coal quality parameters, the net coal output.

Excluding or reducing the influence of quality parameters of coal in seams and the impact of coal output on the progress and production costs can significantly hamper the assessment of the potential (economic value) of specific geological and mining assets. This applies particularly to mining activities in new mining areas and deposits.

The studies were conducted with the use of a dedicated simulation model allowing for the measurement of the direction and strength of the impact of the net calorific value, ash and sulphur content and net coal output (coal yield) on the amount and variability of revenues, costs and, finally, the value of geological and mining projects. For this purpose, the author's formulas for estimating fixed and variable costs as a function of variable net coal output (coal yield) were also developed.

The results of the studies were presented as scenario analysis.

The obtained results indicate a significant impact of calorific value and waste rock content indicated by the variable net coal output (coal yield) on the level of generated revenues, costs and projected valuations of hypothetical activities of a hard coal mine.

It has been shown that a change of $1 \mathrm{GJ}$ in calorific value may result in a $3.57-4.76 \%$ increase/ /decrease in total revenues. In the case of coal deposits, for which the effective coal yield can vary between $60-80 \%$, there can be an expected change in mining cost of coal production by as much as $53.0 \%$ in this range.

The NPV estimation error, at variability of calorific value in the range between $21-27 \mathrm{GJ} / \mathrm{Mg}$, may vary within the range $0-78 \%$, while the decrease in coal output by $18 \%$ can lower the valuation of mining operations by up to $872.4 \%$ due to the characteristics of the NPV method and the developed baseline scenario $(\mathrm{NPV} \approx 0)$.

The paper has not fully addressed the scope of the analyzed issue. The presented paper is a part of a larger work on guidelines allowing for the proper valuation of geological and mining assets, taking into account additional estimation errors of average values of quality parameters of extracted minerals. 